\title{
MOLECULAR AND MORPHOLOGICAL CHARACTERISATION OF FLATWORM LARVAE PARASITISING ON FISH IN CAT TIEN NATIONAL PARK, VIETNAM
}

\author{
Sergey G. Sokolov ${ }^{1}$, Ilya I. Gordeev ${ }^{2,3}$ \\ ${ }^{1}$ A.N. Severtsov Institute of Ecology and Evolution of RAS, Russia \\ ${ }^{2}$ Russian Federal Research Institute of Fisheries and Oceanography, Russia \\ ${ }^{3}$ Lomonosov Moscow State University, Russia \\ e-mail: gordeevilya@bk.ru
}

Received: 21.05.2020. Revised: 11.06.2020. Accepted: 12.07.2020.

\begin{abstract}
Cat Tien National Park in southern Vietnam provides a unique opportunity to study the diversity of parasites associated with animals of the plains of tropical forests and lowland river basins in Southeast Asia. In this study we provide morphological description and phylogenetic analysis based on partial sequences of the 28S rRNA gene of metacercariae belonging to five species: Clinostomum sp., Posthodiplostomum sp. 1, Posthodiplostomum sp. 2, Crassiphialinae gen. sp. 1 and Crassiphialinae gen. sp. 2, collected in four species of freshwater fish (Rasbora paviana, Trichopodus trichopterus, Anabas testudineus and Channa striata). The digenean Clinostomum sp. was found to be phylogenetically close (possibly conspecific) to metacercaria of Clinostomum sp. recorded in Australia. There are no sequences in the GenBank database identical to any Posthodiplostomum spp. nor two other crassiphialine metacercariae found by us. Phylogenetic analysis supports the sister position of Crassiphialinae gen. sp. 1 to the Uvulifer spp. + Crassiphiala spp. group of crassiphialine trematodes. At the same time, phylogenetic relationships of Crassiphialinae gen. sp. 2 were poorly resolved. We also provide morphological description, cox1 and 28S rRNA genes-based reconstruction of phylogeny for the plerocercoid of solenophorid cestode Scyphocephalus sp. ex liver of Trichopodus trichopterus. Phylogenetic analyses unite plerocercoid of Scyphocephalus sp. in one group with solenophorid Duthiersia expansa, while the type species of the genus Scyphocephalus - S. bisulcatus - appears as a sister to Duthiersia fimbriata on the tree. Thus, phylogenetic data cast doubt on both the monotypy and the monophyly of the genus Scyphocephalus. This is the second record of plerocercoids of solenophorids and the first one of fish as second intermediate host of this cestode family.
\end{abstract}

Key words: Clinostomum, Crassiphialinae, fresh waters, metacercariae, plerocercoids, Posthodiplostomum, Scyphocephalus, tropics

\section{Introduction}

National parks and wildlife sanctuaries are essential for the preservation of native biodiversity of relevant natural communities. Untouched nature in the Cat Tien National Park in southern Vietnam provides a unique opportunity to study the diversity of parasites associated with animals of the plains of tropical forests and lowland river basins in Southeast Asia. Most of the Cat Tien National Park's territory is covered by rain forest with a few large permanent water bodies (Tordoff et al., 2004). However, temporal streams and ponds that occur in the forest during the wet season are of no less interest in terms of metazoan parasites' life cycle investigation. Temporary water bodies are the habitat of truly aquatic animals, and due to their shallow depth, are accessible to a wide range of terrestrial, near-water and amphibiotic hosts, which makes them an ideal environment for parasitic larvae distribution and the successful development of a fish-borne zoonosis.
The fauna of trematodes and cestodes parasitising in the metacercarial and metacestoid phases on fish in the oriental zoogeographical region is still poorly resolved, despite certain achievements in this field (e.g. Pandey \& Agrawal, 2013; Gupta, 2016; Choudhary et al., 2017; Patarwut et al., 2020). Many species of metacercariae that parasitise on fish in this region are able to infect humans (Rim et al., 2008; De \& Le, 2011; Hung et al., 2015), which also gives the study of their fauna practical significance.

The species identification of the larval stages of parasitic worms is a problem that all parasitologists encounter. Adequate identification of larvaelike forms of helminths is possible only with a combination of morphological and molecular genetic approaches (Galazzo et al., 2002; Faltýnková et al., 2014). In this paper, we provide morphological and molecular data on metacercariae and plerocercoids collected from fish that inhabit both permanent and temporal water bodies in the Cat Tien National Park. 


\section{Material and Methods}

\section{Study area}

Cat Tien National Park $\left(11.35-11.80^{\circ} \mathrm{N}\right.$, 107.17-107.57 E) is located in District Tân Phú, Dong Nai Province in South Vietnam (Tordoff et al., 2004). The topography of Cat Tien National Park varies greatly among the three sectors: Cat Loc, Nam Cat Tien, and Tay Cat Tien. The first one is rather hilly, although altitudes only reach $659 \mathrm{~m}$ a.s.1., the hills are relatively steep. The other two sectors (Nam Cat Tien and Tay Cat Tien) are situated in the lowlands. The topography of these sectors is characterised by low, gentle hills. The River Dong Nai, the second largest river in southern Vietnam, flows through the national park (Tordoff et al., 2004).

Cat Tien National Park is a well-developed protected area with a long history of efforts to preserve the pristine rainforest (Nguyen \& Yen, 2013). The uniqueness of the ecosystem and the status of the protected area attract scientists who are actively studying the flora (Blanc et al., 2000), soil formation (Chernov et al., 2019), climate (Deshcherevskaya et al., 2013) and other aspects of tropical forest life.

\section{Sample collection and morphological observations}

All fish were caught between 16 November 2017 and 14 December 2017 during an expedition carried out within the framework of the Russian-Vietnamese Tropical Centre (Gordeev et al., 2018; Sokolov \& Gordeev, 2019). Fish specimens in temporal water bodies (Nui Tuong ponds, the brook Da Brout and an unnamed pond) were caught using hand nets and fish net traps. Specimens from the Bao Sao (Crocodile) Lake were provided by employees of the Cat Tien National Park. Immediately after capture, specimens were dissected using standard methods (BykhovskayaPavlovskaya, 1985; Klimpel et al., 2019). At all, 57 fish specimens were examined in this research: one Rasbora paviana Tirant, 1885 (total length (TL) $7.4 \mathrm{~cm}$; weight $3.91 \mathrm{~g}$ ) of the $\mathrm{Cy}-$ prinidae, 49 Trichopodus trichopterus (Pallas, 1770) (TL 4.0-10.5 cm; weight 1.17-16.44 g) of the Osphronemidae, six Anabas testudineus (Bloch, 1792) (TL 6.4-10.6 cm; 5.84-37.46 g) of the Anabantidae, and one Channa striata (Bloch, 1793) (TL $14.9 \mathrm{~cm}$; weight $30.55 \mathrm{~g}$ ) of the Channidae. Worms collected for morphological study were taken out of the cysts using dissecting needles and fixed in hot $70 \%$ ethanol, stained with acetocarmine and mounted in Canadian balsam.
All the measurements were made in micrometres based on one specimen. Ecological terms followed Bush et al. (1997). Host species were identified by Dr Ekaterina Vasilyeva (Zoological Museum of Lomonosov Moscow State University, Russia). Specimens destined for molecular analysis were fixed in $96 \%$ ethanol and stored at $-18^{\circ} \mathrm{C}$. The whole mounts were deposited in the Museum of Helminthological Collections at the Centre of Parasitology of the A.N. Severtsov Institute of Ecology and Evolution of RAS (IPEE RAS) in Moscow, Russia.

\section{DNA extraction, amplification and sequencing}

The total DNA was extracted from 96\% ethanol-fixed metacercariae using a «hot shot» technique (Truett, 2006). The nuclear 28S rRNA gene of trematode larvae was amplified using the polymerase chain reaction (PCR) with the primers DIG12 (5'-AAGCATATCACTAAGCGG-3') and 1500R (5'-GCTATCCTGAGGGAAACTTCG-3'), which were described earlier (Tkach et al., 2003). The initial PCR was performed in a total volume of $20 \mu \mathrm{l}$ that contained $0.25 \mathrm{mM}$ of each primer pair, $1 \mu \mathrm{DNA}$ in water, $1 \times$ Taq buffer, $1.25 \mathrm{mM}$ dinucleotide triphosphates (dNTPs), $1.5 \mathrm{mM} \mathrm{MgCl} 2$ and 1 unit of Taq polymerase. The amplification was carried out in a GeneAmp 9700 (Applied Biosystems) with a $3-\mathrm{min}$. denaturation hold at $94^{\circ} \mathrm{C}, 40$ cycles of $30 \mathrm{~s}$ at $94^{\circ} \mathrm{C}, 30 \mathrm{~s}$ at $55^{\circ} \mathrm{C}$ and $2 \mathrm{~min}$. at $72^{\circ} \mathrm{C}$, and a $7-\mathrm{min}$. extension hold at $72^{\circ} \mathrm{C}$. Negative and positive controls were amplified using both primers. The PCR products were directly sequenced using the ABI Big Dye Terminator v.3.1 Cycle Sequencing Kit, as recommended by the manufacturer, with the internal sequencing primers (Tkach et al., 2003). The PCR products were analysed using an Applied Biosystems 3130xl Genetic Analyser at the Russian Federal Research Institute of Fisheries and Oceanography. Unfortunately, an attempt to obtain sequences of ITS1-5.8S-ITS2 r DNA locus for all studied metacercariae using universal primers BD1 (5'-GTCGTAACAAGGTTTCCGTA-3') and BD2 (5'-TATGCTTAARTTCAGCGGGT-3') (Luton et al., 1992) was unsuccessful.

The total DNA was extracted from one 96\% ethanol-fixed plerocercoid using Wizard SV Genomic DNA Purification System (Promega), as recommended by the manufacturer. The nuclear 28S rRNA gene of the cestode larva was amplified (PCR) with the primers ZX-1 (5'- ACCC- 
GCTGAATTTAAGCATAT-3'), 1500R (5'-GCTATCCTGAGGGAAACTTCG-3'), LSU 300F (5'-CAAGTACCGTGAGGGAAAGTTG-3'), $1090 \mathrm{~F}$ (5'-TGAAACACGGACCAAGG-3'), LSU 1200F (5'-CCCGAAAGATGGTGAACTATGC-3'), ECD2 (5'-CTTGGTCCGTGTTTCAAGACGGG-3'), which were described by Waeschenbach \& Littlewood (2017). The cox 1 of the same specimen was amplified using the polymerase chain reaction (PCR) with the primers PBI-cox1F_PCR (5'-CATTTTGCTGCCGGTCARCAYATGTTYTGRTTTTTTGG-3'), PBI-cox1R PCR (5'-CCTTTGTCGATACTGCCAAARTAATGCATDGGRAA-3'), which were described by Waeschenbach \& Littlewood (2017). The initial PCR was performed in a total volume of $20 \mu \mathrm{l}$ that contained $0.25 \mathrm{mM}$ of each primer pair, $1 \mu \mathrm{DNA}$ in water, $1 \times$ Taq buffer, $1.25 \mathrm{mM}$ dinucleotide triphosphates (dNTPs), $1.5 \mathrm{mM} \mathrm{MgCl} 2$ and 1 unit of Taq polymerase. The amplification was carried out by Eurogen (Moscow) with a 3-min. denaturation hold at $94^{\circ} \mathrm{C}, 40$ cycles of $30 \mathrm{~s}$ at $94^{\circ} \mathrm{C}, 30 \mathrm{~s}$ at $55^{\circ} \mathrm{C}\left(\operatorname{cox} 1-60^{\circ} \mathrm{C}\right)$ and $2 \mathrm{~min} .(\operatorname{cox} 1-1 \mathrm{~min})$ at $72^{\circ} \mathrm{C}$, and a 10 -min. extension hold at $72^{\circ} \mathrm{C}$. Negative and positive controls were amplified using all primers. The PCR products were directly sequenced using the ABI Big Dye Terminator v.3.1 Cycle Sequencing Kit, as recommended by the manufacturer, with the PCR primers for $28 \mathrm{~S}$ and with sequencing primers PBI-cox $1 \mathrm{~F}$ _seq $\left(5^{\prime}-\right.$ CATTTTGCTGCCGGTCA-3'), PBI-cox1R_seq (5'- TAATGCATDGGRAAAAAAC-3') for cox1 (Waeschenbach \& Littlewood, 2017). The PCR products were analysed by Eurogen (Moscow).

\section{Alignment and phylogenetic analysis}

Partial sequence of the 28S rRNA and cox1 gene, used in our study to evaluate the phylogenetic relationships, were assembled using the Geneious ver. 10.0.5 software and aligned with sequences retrieved from the Genbank database (Electronic Supplement 1; Electronic Supplement 2) using the ClustalW DNA weight matrix within the MEGA
10.0.5 software alignment explorer (Kumar et al., 2018) selected using the BLAST search and Phylogenetic analysis of the nucleotide sequences was undertaken using the maximum likelihood (ML) and Bayesian (BI) methods. Phylogenetic trees using ML and BI methods were reconstructed using the MEGA 10.0.5 (Kumar et al., 2018) and MrBayes v. 3.6.2 software (Ronquist \& Huelsenbeck, 2003), respectively. Best nucleotide substitution model for the dataset was estimated using jModelTest version 0.1.1 software (Posada, 2008). In both methods, the general time-reversible model GTR $+\mathrm{G}+\mathrm{I}$ was used based on the Aikake Information Criteria (AIC). A Bayesian algorithm was performed using the Markov chain Monte Carlo (MCMC) option with ngen $=10000000$, nruns $=4$, nchains $=4$ and samplefreq $=1000$. The burn-in values were 2500000 for the «sump» and «sumt» options. The robustness of the phylogenetic relationship was estimated using bootstrap analysis with 1000 replications (Felsenstein, 1985) for ML and with posterior probabilities for BI (Ronquist \& Huelsenbeck, 2003). The values of p-distance for solenophorid cestodes that are given in Table 1 were calculated using MEGA 10.0.5 (Kumar et al., 2018).

\section{Results}

Based on morphology, metacercariae and plerocercoids were identified as Clinostomum sp., Posthodiplostomum sp. 1, Posthodiplostomum sp. 2, Crassiphialinae gen. sp. 1, Crassiphialinae gen. sp. 2 and Scyphocephalus sp.

\section{Clinostomum sp.}

Host: Rasbora paviana.

Site of infection: outer surface of an intestine.

Location: Bao Sao (Crocodile) Lake, $11.459444^{\circ} \mathrm{N}, 107.344167^{\circ} \mathrm{E}$.

Prevalence and intensity: one of one host; two worms/host specimen.

Representative DNA sequences: partial 28S rRNA gene sequence was deposited in Genbank (NCBI) as MT406143.

Table 1. Pairwise comparison of nucleotide sequence differences (p-distance, \%) in the cox1 (above the diagonal) and 28S rRNA (below the diagonal) genes among solenophorid cestodes

\begin{tabular}{|l|c|c|c|c|c|}
\hline \multicolumn{1}{|c|}{ Species } & Scyphocephalus sp. & $\begin{array}{c}\text { Scyphocephalus } \\
\text { bisulcatus }\end{array}$ & $\begin{array}{c}\text { Duthiersia } \\
\text { expansa }\end{array}$ & $\begin{array}{c}\text { Duthiersia } \\
\text { fimbriata }\end{array}$ & $\begin{array}{c}\text { Bothridium } \\
\text { pithonis }\end{array}$ \\
\hline Scyphocephalus sp. & - & 14.9 & $2.7 / 8.4^{*}$ & 15.5 & 17.1 \\
\hline Scyphocephalus bisulcatus & 3.6 & - & $14.8 / 15.7$ & 13.2 & 16.6 \\
\hline Duthiersia expansa & 1.4 & 3.4 & - & $15.9 / 15.9$ & $17.1 / 16.5$ \\
\hline Duthiersia fimbriata & 4.3 & 3.1 & 3.9 & - & 15.7 \\
\hline Bothridium pithonis & 8.1 & 7.5 & 7.5 & 8.1 & - \\
\hline
\end{tabular}

Note: *-sequences of cox1 gene with Genbank numbers KY552895/ KY552894. 
Description: Body elongate-oval, $3256 \times 999 \mu \mathrm{m}$ (Fig. 1A). Tegument aspinose. Anterior end with weakly developed oral collar. Forebody $15.9 \%$ of body length. Oral sucker rounded, terminal, smaller than ventral sucker, $225 \times 250 \mu \mathrm{m}$. Ventral sucker rounded, $500 \times 438 \mu \mathrm{m}$. Oral sucker to ventral sucker width ratio 1:1.75 Prepharynx absent. True pharynx absent, but distinct pharyngeal chamber surrounded by dense pharyngeal gland present. Intestine bifurcating just posterior to pharyngeal chamber. Caeca extending to posterior end of body. Testes two, tandem, inter-testicular space wide. Anterior testis irregularly shaped, with irregular outline, $350 \times 286 \mu \mathrm{m}$. Posterior testis almost triangular, slightly irregular in outline, $313 \times 350 \mu \mathrm{m}$. Cirrus-sac ovoid, $225 \times 123 \mu \mathrm{m}$, dextral to anterior testis. Genital pore in mid-level of body, dextro-submedian. Ovary small, rounded, entire, dextro-submedian, $125 \times 125 \mu \mathrm{m}$. Anlage of oötype inter-testicular, median. Uterus forming several loops in inter-testicular space, ascending around left margin of anterior testis, and distally forming tubular well developed uterine sac. Uterine sac extending anteriorly to short distance from posterior border of ventral sucker. Vitellarium undeveloped. Excretory vesicle V-shaped.

\section{Phylogenetic data}

A partial sequence of our specimen's 28S rRNA (1313 bp) is identical to metacercaria of Clinostomum sp. (AY222175) ex Hypseleotris galii (Ogilby, 1898), Moggil Creek, Queensland, Australia. Unfortunately, no morphological information on this sample is available (Olson et al., 2003). On the phylogenetic tree (Fig. 2), both metacercariae are members of the Clinostomum spp. group that also includes Clinostomum complanatum (Rudolphi, 1814), C. cutaneum Paperna, 1964, and C. phalacrocoracis Dubois, 1931. This group is weakly supported by BI analysis and moderately supported by ML analysis, but it was poorly resolved internally.
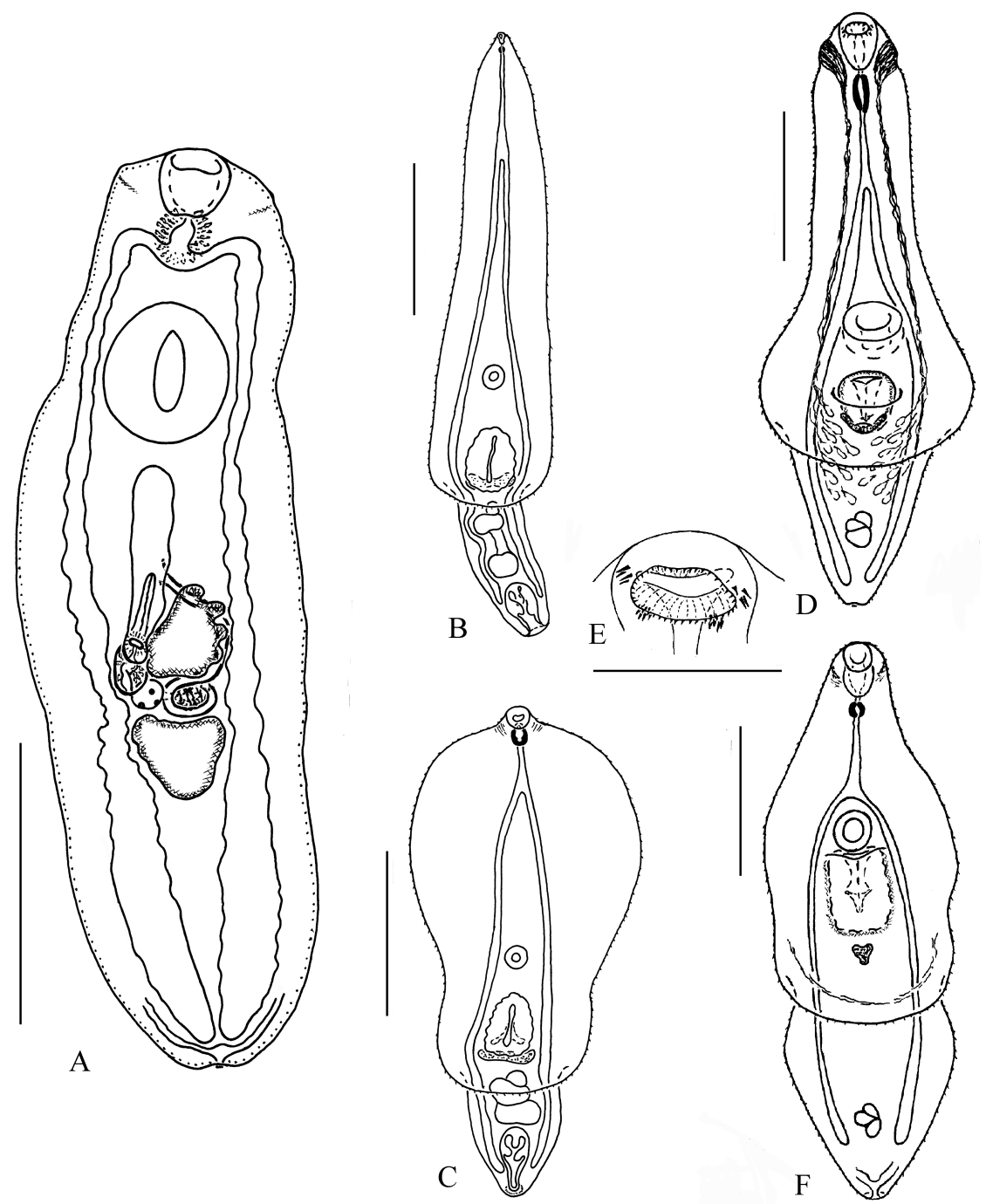

Fig. 1. Metacercariae from fish of Cat Tien National Park. Designations: A - Clinostomum sp., whole view; B - Posthodiplostomum sp. 1 ex Anabas testudineus, whole view; C - Posthodiplostomum sp. 2, whole view; D, E - Crassiphialinae gen. sp. 1, whole view (D), mouth opening area with rows of large tegumental spines (E); F - Crassiphialinae gen. sp. 2, whole view. Scale bars: A - $1 \mathrm{~mm}$; B - $0.4 \mathrm{~mm}$; C $-0.3 \mathrm{~mm}$; D, F - $0.15 \mathrm{~mm}$; E $-0.05 \mathrm{~mm}$. 


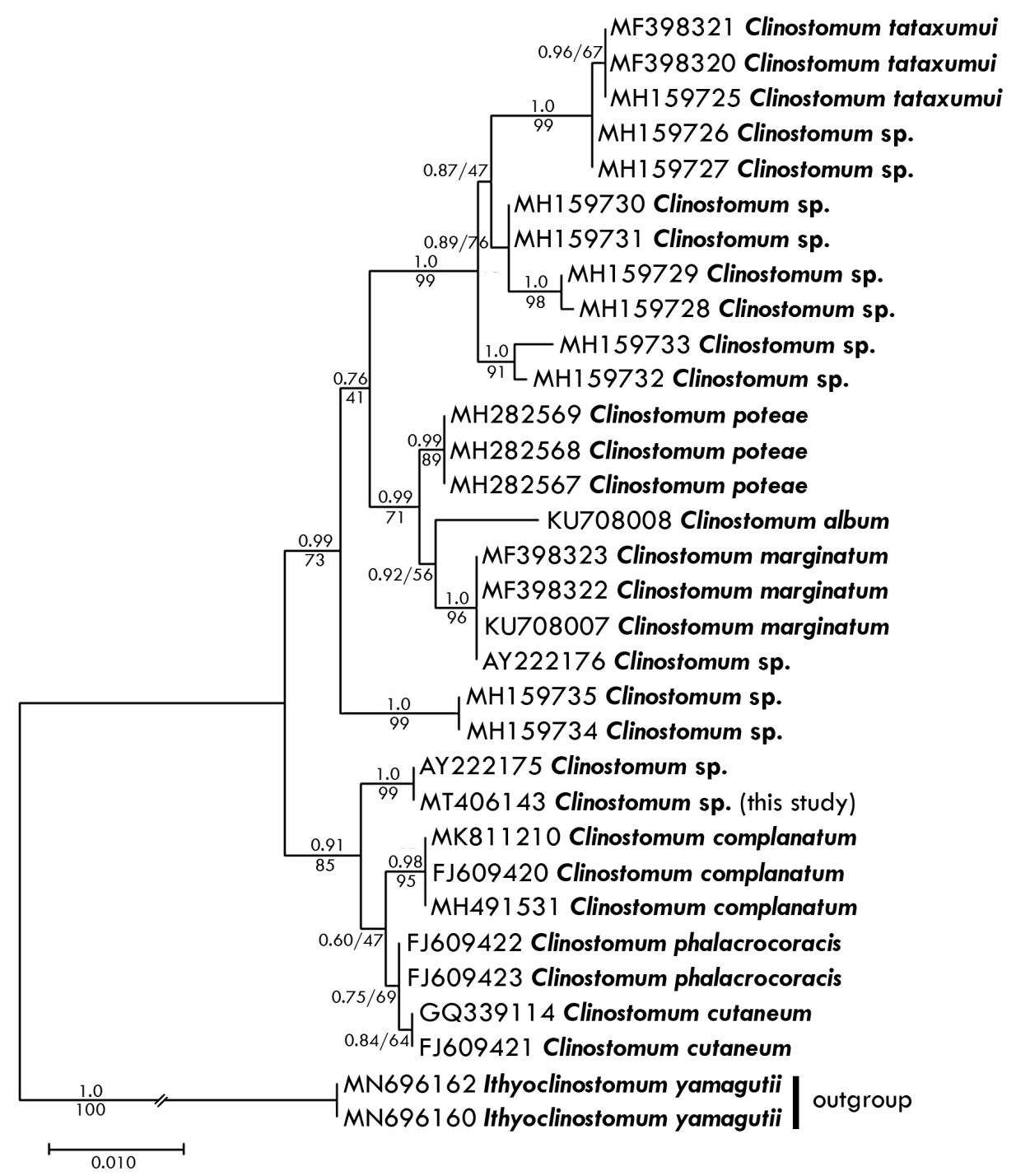

Fig. 2. Phylogenetic position of metacercaria of Clinostomum sp. based on the analysis of 28S rRNA gene partial sequences (1313 bp). Nodal numbers are posterior probability values for BI/bootstrap values for ML.

\section{Posthodiplostomum sp. 1}

Hosts: Trichopodus trichopterus and Anabas testudineus.

Site of infection: liver.

Location: ponds Nui Tuong, $11.406667^{\circ} \mathrm{N}$, $107.4075^{\circ} \mathrm{E}$.

Prevalence and intensity: one of 25 hosts; one worm/host specimen (T. trichopterus) and one of six hosts; 26 worms/host specimen (A. testudineus).

Representative DNA sequences: two partial 28S rRNA gene sequences were deposited in Genbank (NCBI) as MT394050 (ex A. testudineus) and MT394051 (ex T. trichopterus).

Description: Body bipartite, with elongate, lancet-shaped forebody and subcylindrical or conical hindbody (Fig. 1B). Total length $1613 \mu \mathrm{m}$, maximal width $313 \mu \mathrm{m}$ at level of holdfast organ. Forebody covered with small spines. Hindbody $375 \mu \mathrm{m}$ in length, lodging primordial testes and ovary, and anlage of copulatory bursa with pri- mordial fleshy prepuce. Oral sucker subterminal, $40 \times 23 \mu \mathrm{m}$. Pseudosuckers absent. Ventral sucker rounded, $73 \times 63 \mu \mathrm{m}$, at $875 \mu \mathrm{m}$ from anterior extremity. Oral sucker to ventral sucker width ratio $1: 2.71$. Holdfast organ suboval, $182 \times 149 \mu \mathrm{m}$, distinctly separated from ventral sucker. Proteolytic gland transverse-oval, at level of posterior edge of holdfast organ. Prepharynx very short. Pharynx $23 \times 13 \mu \mathrm{m}$. Oesophagus $53 \mu \mathrm{m}$. Intestine bifurcating in anterior quarter of forebody. Caeca terminating blindly at midlevel of primordium of copulatory bursa.

\section{Posthodiplostomum sp. 2}

Host: Channa striata.

Site of infection: eye retina.

Location: unnamed pond, $11.432222^{\circ} \mathrm{N}$, 107.427778 ${ }^{\circ} \mathrm{E}$.

Prevalence and intensity: one of one host; two worms/host specimen. 
Representative DNA sequences: partial $28 \mathrm{~S}$ rRNA gene sequence was deposited in Genbank (NCBI) as MT394045.

Description: Body bipartite, with foliate forebody and conical hindbody (Fig. 1C). Total length $900 \mu \mathrm{m}$, maximal width $413 \mu \mathrm{m}$ at border between anterior and middle third of forebody. Forebody covered with small spines. Hindbody $238 \mu \mathrm{m}$ in length, lodging primordial testes and ovary, and anlage of copulatory bursa with primordial fleshy prepuce. Oral sucker subterminal, $36 \mu \mathrm{m}$ in width. Pseudosuckers absent. Ventral sucker rounded, $49 \times 43 \mu \mathrm{m}$, at $438 \mu \mathrm{m}$ from anterior extremity. Oral sucker to ventral sucker width ratio $1: 1.18$. Holdfast organ suboval, $125 \times 92 \mu \mathrm{m}$, distinctly separated from ventral sucker. Proteolytic gland transverse-oval, at level of posterior edge of holdfast organ. Prepharynx not observed. Pharynx $26 \mu \mathrm{m}$ in width. Oesophagus $66 \mu \mathrm{m}$. Intestine bifurcating in anterior quarter of forebody. Caeca terminating blindly at level of posterior third of primordium of copulatory bursa.

\section{Crassiphialinae gen. sp. 1}

Host: Trichopodus trichopterus.

Site of infection: liver.

Location: brook Da Brout, 11.441944 $\mathrm{N}$, $107.428889^{\circ} \mathrm{E}$.

Prevalence and intensity: four of 24 hosts; $2-8$ worms/host specimen.

Representative DNA sequences: partial 28S rRNA gene sequence was deposited in Genbank (NCBI) as MT394053.

Description: Body bipartite, covered with small spines (Fig. 1D). Total length $613 \mu \mathrm{m}$, maximal width $213 \mu \mathrm{m}$ at level of holdfast organ. Forebody elongate, lancet-shaped, slightly concave ventrally. Hindbody conical, $188 \mu \mathrm{m}$ in length. Oral sucker subterminal, $59 \times 43 \mu \mathrm{m}$, mouth opening surrounded by two rows of large spines (Fig. 1E). Pseudosuckers well developed, overlapping level of posterior part of oral sucker and anterior part of pharynx, penetrated by ducts of large gland cells lying in parenchyma between holdfast organ and anlage of gonads. Ventral sucker transverse-oval, $59 \times 69 \mu \mathrm{m}$, at $300 \mu \mathrm{m}$ from anterior extremity. Oral sucker to ventral sucker width ratio $1: 1.61$. Holdfast organ cylindrical, with deep median cavity, $63 \times 63 \mu \mathrm{m}$, separated from ventral sucker. Proteolytic gland almost Vshaped, at level of posterior edge of holdfast organ. Prepharynx very short. Pharynx $33 \times 16 \mu \mathrm{m}$. Oesophagus $83 \mu \mathrm{m}$. Intestine bifurcating at bor- der between anterior and middle third of forebody. Caeca extending to posterior end of body. Anlage of gonads in middle part of hindbody.

\section{Crassiphialinae gen. sp. 2}

Host: Trichopodus trichopterus.

Site of infection: liver.

Location: brook Da Brout, 11.441944 $\mathrm{N}$, 107.428889 ${ }^{\circ} \mathrm{E}$.

Prevalence and intensity: one of 24 hosts; eight worms/host specimen.

Representative DNA sequences: partial 28S rRNA gene sequence was deposited in Genbank (NCBI) as MT394052.

Description: Body bipartite, covered with small spines (Fig. 1F). Total length $588 \mu \mathrm{m}$, maximal width $200 \mu \mathrm{m}$ at level of ventral sucker. Forebody elongate, foliate, slightly concave ventrally. Hindbody conical, $250 \mu \mathrm{m}$ in length. Oral sucker subterminal, $56 \times 36 \mu \mathrm{m}$. Pseudosuckers absent. Ventral sucker rounded, $46 \times 40 \mu \mathrm{m}$, at $175 \mu \mathrm{m}$ from anterior extremity. Oral sucker to ventral sucker width ratio 1:1.09. Holdfast organ cylindrical, with deep median cavity, $99 \times 59 \mu \mathrm{m}$, just posterior to from ventral sucker. Proteolytic gland triangular, distinctly separated from posterior edge of holdfast organ. Prepharynx very short. Pharynx $23 \times 16 \mu \mathrm{m}$. Oesophagus $83 \mu \mathrm{m}$. Intestine bifurcating at border between anterior and middle third of forebody. Caeca terminating blindly some distance from posterior end of body. Anlage of gonads at border between middle and posterior third of hindbody.

Phylogenetic data for crassiphialine metacercariae The 28S rDNA gene-based phylogenetic analysis unites crassiphialines Posthodiplostomum sp. 1 and Posthodiplostomum sp. 2 into one well-supported group that is also including Posthodiplostomum sp. (AB693170), collected ex Channa argus (Cantor, 1842) in Japan (Nguyen et al., 2012) (Fig. $3)$. Within the group Posthodiplostomum sp. 2 and Japanese Posthodiplostomum sp. appears as a sister species. Crassiphialinae gen. sp. 1 is wellsupported sister taxon to the Uvulifer spp. + Crassiphiala spp. group of trematodes, however the phylogenetic relationships of Crassiphialinae gen. sp. 2 were poorly resolved (Fig. 3).

\section{Scyphocephalus sp.}

Host: Trichopodus trichopterus.

Site of infection: liver.

Location: brook Da Brout, 11.441944 $\mathrm{N}$, $107.428889^{\circ} \mathrm{E}$. 


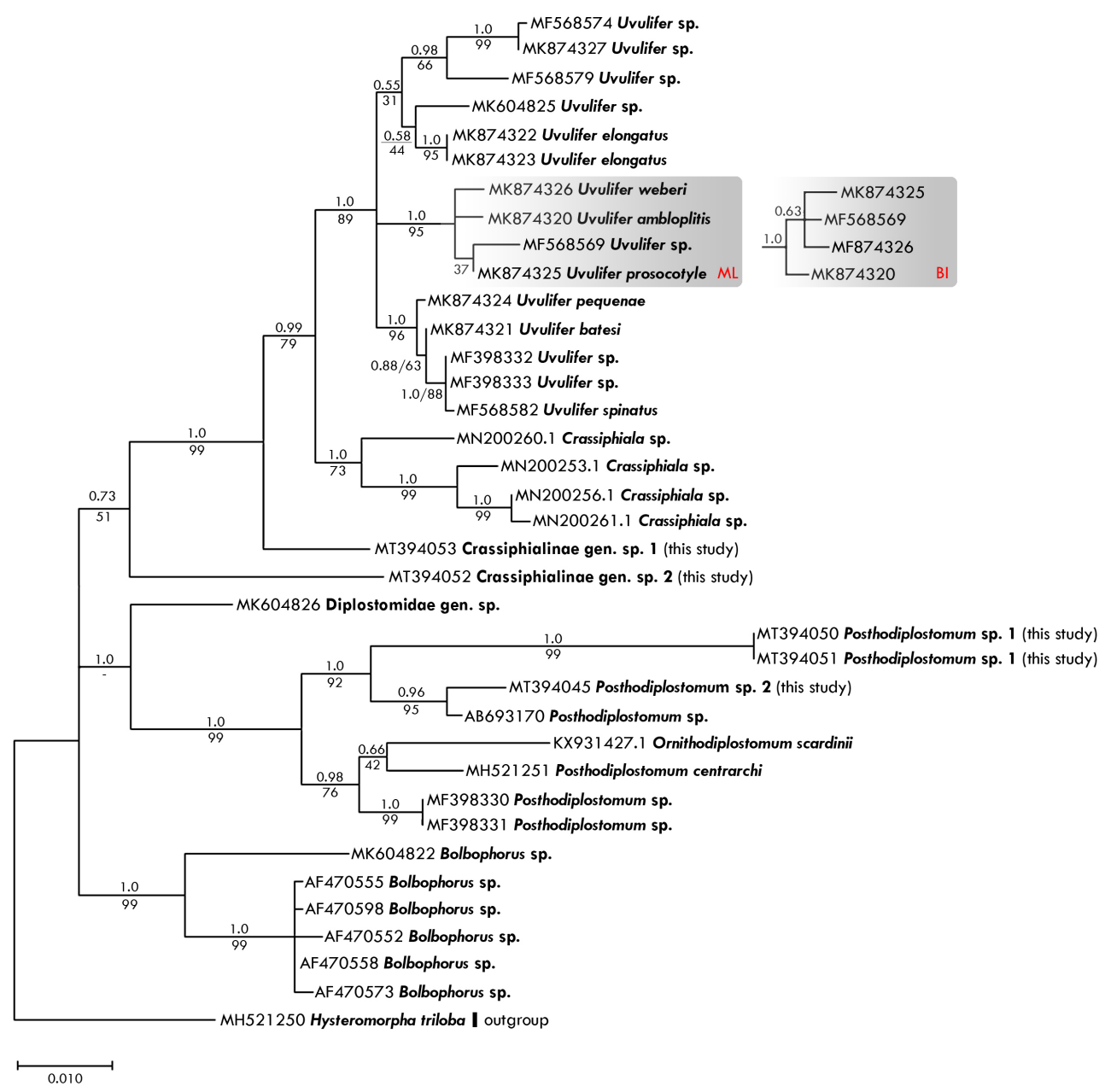

Fig. 3. Phylogenetic position of crassiphialine metacercariae based on the analysis of $28 \mathrm{~S}$ rRNA gene partial sequences (1003 bp). Nodal numbers are posterior probability values for BI/bootstrap values for ML. Clades with grey shading have different topology in the BI and ML trees.

Prevalence and intensity: one of 24 hosts; three worms/host specimen.

Representative DNA sequences: two partial 28S rRNA and cox1 genes sequences deposited in Genbank (NCBI) as MT408587 and MT375386, respectively.

Description: Body ovoid, $518 \times 490 \mu \mathrm{m}$. Scolex cup-shaped, with deep apical cavity and two rudimentary bothria (Fig. 4A,B).

\section{Phylogenetic data}

The 28r rDNA gene-based phylogenetic analysis unites Scyphocephalus sp. in one group with the solenophorid cestode Duthiersia expansa Perrier, 1873 (KY552840) ex Varanus salvator (Laurenti, 1768), Vietnam (Fig. 5). The type species of the genus Scyphocephalus Riggenbach, 1898, S. bisulcatus Riggenbach, 1898 appears as a sister to another species of the genus Duthiersia Perrier, 1873, D. fimbriata (Diesing 1854). The cox1-based analysis (561 bp) also supports the close phylogenetic affinities of Scyphocephalus sp. to $D$. expansa; however, $D$. expansa appears as a paraphyletic taxon (Fig. 6). The values of p-distance for solenophorid cestodes are given in Table 1.

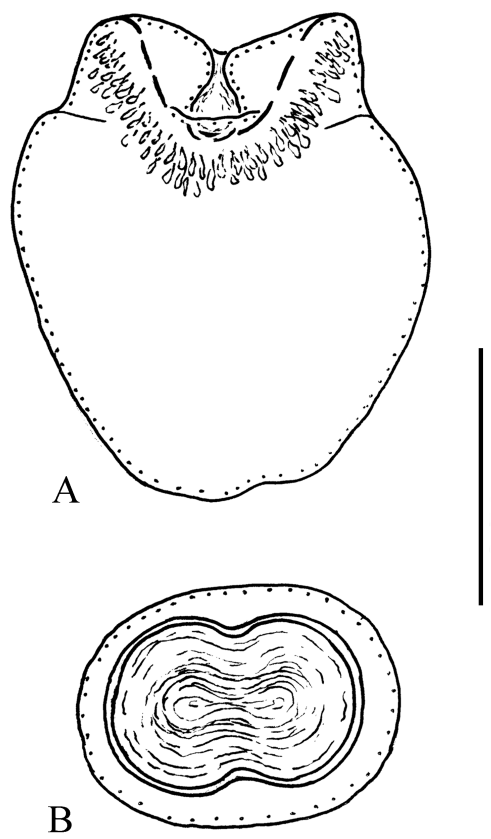

Fig. 4. Plerocercoid of Scyphocephalus sp., dorso-ventral (A) and apical views (B). Scale bar: $0.3 \mathrm{~mm}$. 


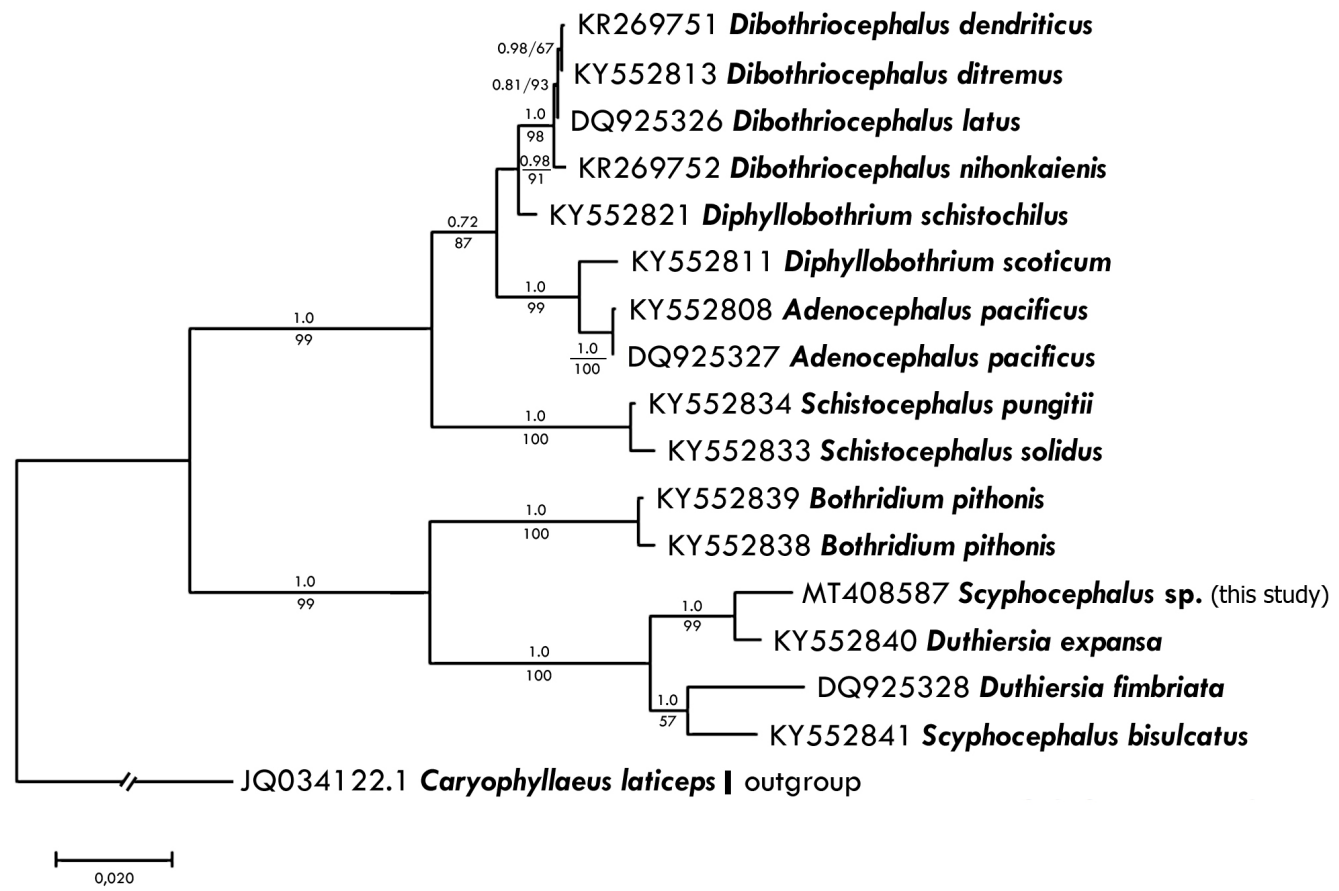

Fig. 5. Phylogenetic position of plerocercoid of Scyphocephalus sp. based on the analysis of 28S rRNA gene partial sequences (1414 bp). Nodal numbers are posterior probability values for BI/bootstrap values for ML.

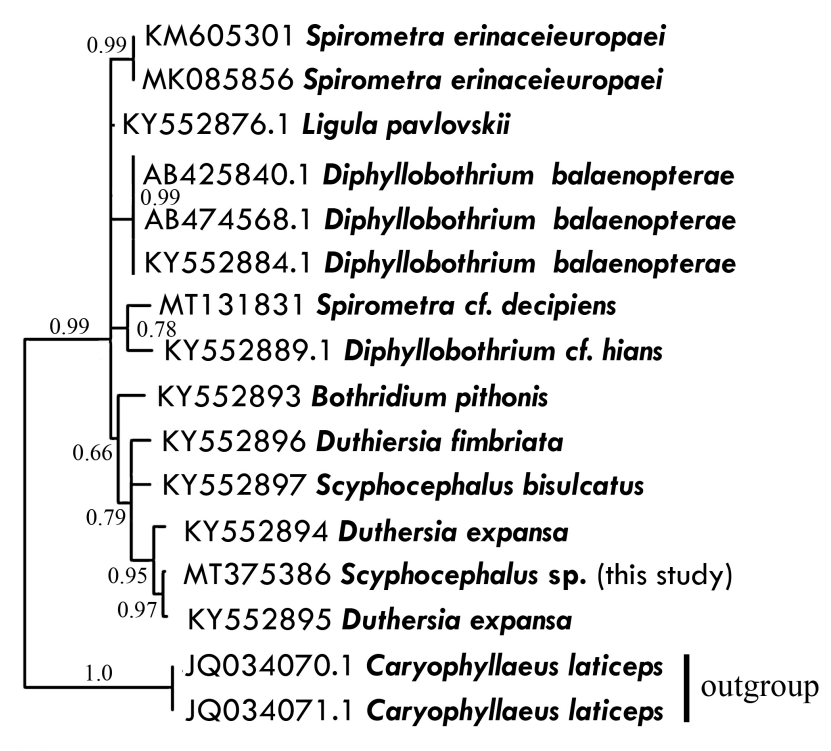

$\longmapsto$

BI

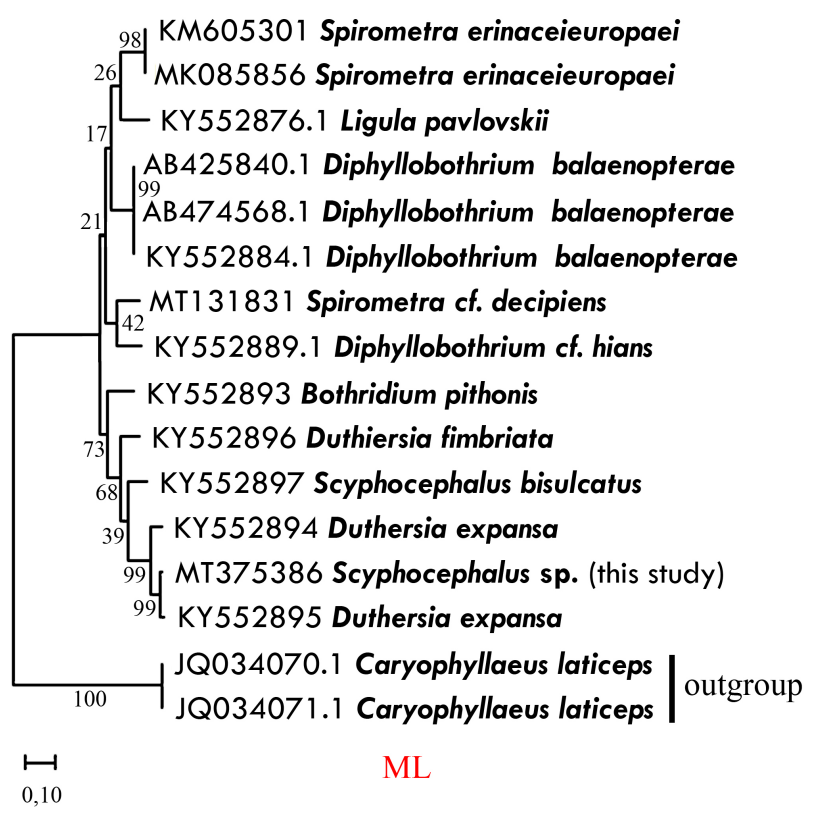

Fig. 6. Phylogenetic position of plerocercoid of Scyphocephalus sp. based on the analysis of cox1 gene partial sequences (553 bp) using BI and ML algorithms. Nodal numbers indicate posterior probabilities/bootstrap values.

\section{Discussion}

Both Clinostomum Leidy, 1856 and Posthodiplostomum Dubois, 1936 are widespread genera of trematodes, the adult stages of which mainly parasitise the piscivorous birds (Dubois, 1968; Locke et al., 2015). In regions with poorly studied fauna, species diagnostics of Clinostomum and Posthodiplostomum metacercariae, based on morphological characters, does not give an adequate and useful result, in view of cryptic diversity in these genera (e.g., Locke et al., 2015; Pérez-Ponce de León et al., 2016; Boone et al., 2018).
This is the first study of the genera Clinostomum and Posthodiplostomum metacercariae parasitising on fish in Vietnam, carried out using molecular methods. Previously, only four species of this genera were recorded in fish in Vietnam, namely Clinostomum complanatum, C. piscidium Southwell \& Prashad, 1918, Posthodiplostomum cuticula (Nordmann, 1832), and $P$. grayi (Verma, 1936) (see Arthur \& Te, 2006; Lysenko, 2013; Guseva et al., 2014). Our Clinostomum sp. was found to be phylogenetically close (possibly conspecific) to metacercaria of Clinostomum sp. recorded in Aus- 
tralia. Presently there are no sequences in the GenBank database identical to any of Posthodiplostomum sp. found by us. Also Posthodiplostomum sp. 1 and Posthodiplostomum sp. 2 differ from each other in body size, suckers ratio and utilisation of host tissues. Current phylogenetic analysis, like the data of our predecessors (e.g. Locke et al., 2010; López-Hernández et al., 2018), does not support the monophyly of the genus Posthodiplostomum.

Crassiphialinae gen. sp. 1 closely fits the morphology of Subuvulifer sabahensis (Fischthal \& Kuntz, 1973), originally described in kingfisher Pelargopsis capensis javana (Boddaert, 1783) in North Borneo, namely forebody shape, morphology of pseudo-suckers and holdfast organ (compare with Fischthal \& Kuntz, 1973). However, the absence of molecular data on the genus Subuvulifer Dubois, 1952 and its life cycle does not allow us to verify this assumption. Crassiphialinae gen. sp. 2 differs from Crassiphialinae gen. sp. 1 by a set of significant morphological features, e.g. lack of pseudo-suckers, shape and position of holdfast organ that are a clear sign of a different generic affiliation. The position of Crassiphialinae gen. sp. 2 on the tree (Fig. 3) suggests that this trematode belongs to a separate and unknown genus.

The morphology of the studied plerocercoids' scolexes is indicative of belonging to the genus Scyphocephalus (see Riggenbach, 1899; Waeschenbach et al., 2017). According to the current concept of the genus Scyphocephalus, it is a monotype taxon, and previously described nominal species $S$. secundus Tubangui, 1938 and S. longus Sawada \& Kugi, 1973 are conspecific to the type species $S$. bisulcatus (see Schmidt \& Kuntz, 1974; Vlnová, 2014). The values of p-distance in the 28S rRNA and cox1 genes in pairs Scyphocephalus sp./S. bisulcatus and Scyphocephalus sp./D. expansa ranged from $1.4-3.6 \%$ and $2.7-12.2 \%$, respectively (Table 1 ). These values correspond to at least the interspecific level of differences in cestodes (e.g. Agustí et al., 2005; Zhang et al., 2014). Together with the topology of the trees (Fig. 5, Fig. 6) these data allow us to consider genera Duthiersia and Scyphocephalus as polyphyletic taxa. The question of the generic affiliation of cestodes included in the Duthiersia spp. + Scyphocephalus spp. clade has no clear solution yet. The taxonomic interpretation of the clade requires the union of all species into one genus or consideration as independent genera of Scyphocephalus bisulcatus, Scyphocephalus sp., Duthiersia fimbriata and all «D. expansa». Thus, the molecular data we obtained cast doubt on not only the monotypy, but also the monophyly of Scyphocephalus.

This study is the second record of solenophorids' plerocercoid and the first on a fish as the second intermediate host of this cestode family. The plerocercoid stage was described earlier only in D. expansa. Pandey \& Rajvanshi (1984) found this metacestode in the amphibian Hoplobatrachus tigerinus Daudin in India.

\section{Conclusions}

The species richness of helminths in the tropics remains a topical question of biogeography, emphasising the importance of obtaining primary faunistic data from different hosts and different regions of this climate zone (Dobson et al., 2008; Poulin, 2010). The short-term collection of fish parasites that we carried out in November and December 2017 in only four of many temporal and permanent water bodies located in the Cat Tien National Park resulted in several years of work to identify the numerous larvae of parasitic flatworms. Following the establishment of Asaccotrema vietnamiense Sokolov \& Gordeev, 2019 in this paper we provide a morphological description and molecular data on the 28S rRNA gene for five species of metacercariae: Clinostomum sp., Posthodiplostomum sp. 1, Posthodiplostomum sp. 2, Crassiphialinae gen. sp. 1 and Crassiphialinae gen. sp. 2, collected from four species of fish. Of these five, only Clinostomum sp. was found to have an identical sequence in GenBank. We also provide a morphological description as well as cox 1 and $28 \mathrm{~S}$ rRNA genes-based phylogeny reconstruction of solenophorid cestode Scyphocephalus sp. Phylogenetic analysis casts doubt on both the monotypy and monophyly of the genus Scyphocephalus. Fish were recorded as the second intermediate host of solenophorids for the first time.

\section{Acknowledgements}

The authors wish to thanks Dr. Alexey Tiunov (IPEE RAS, Russia), Boris Efeykin (Center of Parasitology IPEE RAS, Russia), Dr. Igor Palko, Dr. Irina Semenyuk, Dr. Anna Vasilyeva (Russian-Vietnamese Tropical Center) for help in sampling; Dr. Nguyen Van Ha and Dr. Hien Hoang Van (Institute of Ecology and Biological Resources, VAST, Vietnam) for help in finding literature; Alexander Volkov (VNIRO, Russia) for help in the genetic analysis, and Dr. Ekaterina Vasilyeva (Zoological Museum of Lomonosov Moscow State University, Russia) for help in host fish species identification. This work is a part of the state supported studies in the Center of Parasitology, A.N. Severtsov Institute of Ecology and Evolution of RAS (project no. 0109-2018-0075). 


\section{Supporting Information}

The dataset of 63 sequences of trematodes (Electronic Supplement 1: List of previously published trematode sequences used in the phylogenetic analysis), and 31 sequences of cestodes (Electronic Supplement 2: List of previously published cestode sequences used in the phylogenetic analysis) may be found in the Supporting Information here.

\section{References}

Agustí C., Aznar F.J., Olson P.D., Littlewood D.T.J., Kostadinova A., Raga J.A. 2005. Morphological and molecular characterization of tetraphyllidean merocercoids (Platyhelminthes: Cestoda) of striped dolphins (Stenella coeruleoalba) from the Western Mediterranean. Parasitology 130(4): 461-474. DOI: 10.1017/S0031182004006754

Arthur J.R., Te B.Q. 2006. Checklist of the parasites of fishes of Viet Nam. FAO Fisheries Technical Paper. No. 369/2. Rome: FAO. 133 p.

Blanc L., Maury-Lechon G., Pascal J.P. 2000. Structure, floristic composition and natural regeneration in the forests of Cat Tien National Park, Vietnam: an analysis of the successional trends. Journal of Biogeography 27(1): 141-157. DOI: 10.1046/j.1365-2699.2000.00347.x

Boone E.C., Laursen J.R., Colombo R.E., Meiners S.J., Romani M.F., Keeney D.B. 2018. Infection patterns and molecular data reveal host and tissue specificity of Posthodiplostomum species in centrarchid hosts. Parasitology 145(11): 1458-1468. DOI: 10.1017/ s0031182018000306

Bush A.O., Lafferty K.D., Lotz J.M., Shostak A.W. 1997. Parasitology meets ecology on its own terms: Margolis et al. revisited. Journal of Parasitology 83(4): 575-583. DOI: $10.2307 / 3284227$

Bykhovskaya-Pavlovskaya I.E. 1985. Parasites of fishes. Study Manual. Leningrad: Nauka. 123 p. [In Russian]

Chernov T.I., Zhelezova A.D., Tkhakakhova A.K., Bgazhba N.A., Zverev A.O. 2019. Microbiomes of Virgin Soils of Southern Vietnam Tropical Forests. Microbiology 88(4): 489-498. DOI: 10.1134/S0026261719040040

Choudhary K., Tripathi A., Pandey K.C., Agrawal N. 2017. Morphological and molecular characterisation of three Indian Neascus-type metacercariae (Digenea: Diplostomidae). Parasitology International 66(5): 652-659. DOI: 10.1016/j.parint.2017.06.007

De N.V., Le T.H. 2011. Human infections of fish-borne trematodes in Vietnam: prevalence and molecular specific identification at an endemic commune in Nam Dinh province. Experimental Parasitology 129(4): 355-361. DOI: 10.1016/j.exppara.2011.09.005

Deshcherevskaya O.A., Avilov V.K., Dinh B.D., Tran C.H., Kurbatova J.A. 2013. Modern climate of the Cat Tien National Park (Southern Vietnam): climatological data for ecological studies. Izvestiya - Atmospheric and Ocean Physics 49(8): 819-838. DOI: 10.1134/ S0001433813080021
Dobson A., Lafferty K.D., Kuris A.M., Hechinger R.F., Jetz W. 2008. Homage to Linnaeus: how many parasites? How many hosts? In: J.C. Avise, S.P. Hubbell, F.J. Ayala (Eds.). In the Light of Evolution. Vol. 2: Biodiversity and Extinction. Washington: National Academies Press. P. 63-82.

Dubois G. 1968. Synopsis des Strigeidae et des Diplostomatidae (Trematoda). Mémoires de la Société Neuchâteloise des Sciences Naturelles 10: 1-258.

Faltýnková A., Georgieva S., Kostadinova A., Blasco-Costa I., Scholz T., Skírnisson K. 2014. Diplostomum von Nordmann, 1832 (Digenea: Diplostomidae) in the subArctic: descriptions of the larval stages of six species discovered recently in Iceland. Systematic Parasitology 89(3): 195-213. DOI: 10.1007/s11230-014-9517-0

Felsenstein J. 1985. Confidence limits on phylogenies: an approach using the bootstrap. Evolution 39(4): 783-791. DOI: $10.1111 /$ j.1558-5646.1985.tb00420.x

Fischthal J.H., Kuntz R.E. 1973. Additional digenetic trematodes of birds from North Borneo (Malaysia). Proceedings of the Helminthological Society of Washington 40(2): 245-255.

Galazzo D.E., Dayanandan S., Marcogliese D.J., McLaughlin J.D. 2002. Molecular systematics of some North American species of Diplostomum (Digenea) based on rDNA-sequence data and comparisons with European congeners. Canadian Journal of Zoology 80(12): 2207 2217. DOI: 10.1139/Z02-198

Gordeev I.I., Biserova N.M., Grigorov I.V., Mustafina A.R., Golovaneva M.S. 2018. The experience of ichthyo-parasitological studies in a tropical forest. In: A.M. Orlov, I.I. Gordeev, A.A. Sergeev (Eds.): Prospects for Fisheries and Aquaculture in the Modern World. Moscow: VNIRO. P. 74. [In Russian]

Guseva E.E., Zhokhov A.E., Nguen T.H.T. 2014. Helminth fauna of freshwater fish in central and southern Vietnam. In: D.S. Pavlov, D.D. Zvorykin (Eds.): Ecology of inland waters of Vietnam. Moscow: KMK Scientific Press Ltd. P. 208-224. [In Russian]

Gupta B.K. 2016. Studies on the structure of three new species of strigeids metacercariae from Indian freshwater food fishes. Indian Journal of Pure and Applied Biosciences 4(4): 221-228. DOI: 10.18782/2320-7051.2347

Hung N.M., Dung D.T., Lan Anh, N.T., Van P.T., Thanh B.N., Van Ha N., Van Hien H., Canh L.X. 2015. Current status of fish-borne zoonotic trematode infections in Gia Vien district, Ninh Binh province, Vietnam. Parasites Vectors 8(1): 21. DOI: 10.1186/s13071-015-0643-6

Klimpel S., Kuhn T., Mьnster J., Dцrge D.D., Klapper R., Kochmann J. 2019. Parasites of marine fish and cephalopods. Springer International Publishing. 169 p.

Kumar S., Stecher G., Li M., Knyaz C., Tamura K. 2018. MEGA $\mathrm{X}$ : Molecular evolutionary genetics analysis across computing platforms. Molecular Biology and Evolution 35(6): 1547-1549. DOI: 10.1093/molbe v/msy09

Locke S.A., McLaughlin J.D., Marcogliese D.J. 2010. DNA barcodes show cryptic diversity and a potential physiological basis for host specificity among Diplostomoidea (Platyhelminthes: Digenea) parasit- 
izing freshwater fishes in the St. Lawrence River, Canada. Molecular Ecology 19(13): 2813-2827. DOI: 10.1111/j.1365-294x.2010.04713.x

Locke S.A., Caffara M., Marcogliese D.J., Fioravanti M.L. 2015. A large-scale molecular survey of Clinostomum (Digenea, Clinostomidae). Zoologica Scripta 44(2): 203-217. DOI: 10.1111/zsc. 12096

López-Hernández D., Locke S.A., de Melo A.L., Rabelo É.M.L., Pinto H.A. 2018. Molecular, morphological and experimental assessment of the life cycle of Posthodiplostomum nanum Dubois, 1937 (Trematoda: Diplostomidae) from Brazil, with phylogenetic evidence of the paraphyly of the genus Posthodiplostomum Dubois, 1936. Infection, Genetics and Evolution 63: 95-103. DOI: 10.1016/j.meegid.2018.05.010

Luton K., Walker D., Blair D. 1992. Comparisons of ribosomal internal transcribed spacers from two congeneric species of flukes (Platyhelminthes: Trematoda: Digenea). Molecular and Biochemical Parasitology 56(2): 323-327. DOI: 10.1016/0166-6851(92)90181-I

Lysenko V.N. 2013. Ecological-faunal analysis of parasites of carps (Cyprinidae) of the Viet Nam aquaculture. $\mathrm{Hy}$ drobiological Journal 49(4): 100-112. DOI: 10.1615/ HydrobJ.v49.i4.90 [In Russian]

Nguyen N.T., Yen H.M. 2013. Cat Tien National Park. In: T.C.H. Sunderland, J. Sayer, M.H. Hoang (Eds.): Evidence-based conservation: lessons from the lower $\mathrm{Me}$ kong. Bogor: CIFOR. P. 17-28.

Nguyen T.C., Li Y.C., Makouloutou P., Jimenez L.A., Sato H. 2012. Posthodiplostomum sp. metacercariae in the trunk muscle of northern snakeheads (Channa argus) from the Fushinogawa River, Yamaguchi, Japan. Journal of Veterinary Medical Science 74(10): 1367-1372. DOI: 10.1292/jvms.12-0025

Olson P.D., Cribb T.H., Tkach V.V., Bray R.A., Littlewood D.T.J. 2003. Phylogeny and classification of the Digenea (Platyhelminthes: Trematoda). International Journal for Parasitology 33(7): 733-755. DOI: 10.1016/ s0020-7519(03)00049-3

Pandey K.C., Agrawal N. 2013. Metacercarial fauna of India. Kolkata: Zoological Survey of India. 310 p.

Pandey K.C., Rajvanshi S.L. 1984. Note on metacestode of Duthiersia expansa, 1873. Current Science 53(22): 1218-1219.

Patarwut L., Chontananarth T., Chai J.Y., Purivirojkul W. 2020. Infections of Digenetic Trematode Metacercariae in Wrestling Halfbeak, Dermogenys pusilla from Bangkok Metropolitan Region in Thailand. Korean Journal of Parasitology 58(1): 27-35. DOI: 10.3347/ kjp.2020.58.1.27

Pérez-Ponce de León G., Garcia-Varela M., Pinacho-Pinacho C.D., Sereno-Uribe A.L., Poulin R. 2016. Species delimitation in trematodes using DNA sequences: Middle-American Clinostomum as a case study. Parasitology 143(13): 1773-1789. DOI: 10.1017/ S0031182016001517

Posada D. 2008. jModelTest: phylogenetic model averaging. Molecular Biology and Evolution 25(7): 1253-1256. DOI: $10.1093 / \mathrm{molbev} / \mathrm{msn} 083$
Poulin R. 2010. Latitudinal gradients in parasite diversity: bridging the gap between temperate and tropical areas. Neotropical Helminthology 4(2): 169-177.

Riggenbach E. 1899. Scyphocephalus bisulcatus n. g. n. sp., ein neuer Reptiliencestode. Zoologischer Jahrbücher. Abtheilung für Systematik, Geographie und Biologie der Thiere 12: 145-154.

Rim H.J., Sohn W.M., Yong T.S., Eom K.S., Chai J.Y., Min D.Y., Lee S.H., Hoang E.H., Phommasack B., Insisengmay S. 2008. Fishborne trematode metacercariae detected in freshwater fish from Vientiane Municipality and Savannakhet Province, Lao PDR. Korean Journal of Parasitology 46(4): 253-260. DOI: 10.3347/kjp.2008.46.4.253

Ronquist F., Huelsenbeck J.P. 2003 MrBayes 3: Bayesian phylogenetic inference under mixed models. Bioinformatics 19(12): 1572-1574. DOI: 10.1093/bioinformatics/btg180

Schmidt G.D., Kuntz R.E. 1974. Tapeworms from Philippine reptiles, with two new species of Proteocephalata. Proceedings of the Helminthological Society of Washington 41(2): 195-199.

Sokolov S.G., Gordeev I.I. 2019. Asaccotrema vietnamiense n. gen.; n. sp. (Trematoda: Monorchioidea), a new aberrant representative of lissorchiid trematodes from the sidestripe rasbora, Rasbora paviana Tirant (Actinopterygii: Cyprinidae), Vietnam. Zootaxa 4674(4): 451-462. DOI: 10.11646/zootaxa.4674.4.4

Tkach V.V., Littlewood D.T.J., Olson P.D., Kinsella J.M., Swiderski Z. 2003. Molecular phylogenetic analysis of the Microphalloidea Ward, 1901 (Trematoda: Digenea). Systematic Parasitology 56(1): 1-15. DOI: 10.1023/A:1025546001611

Tordoff A.W., Tran Quoc Bao, Nguyen Duc Tu, Le Manh Hung (Eds.). 2004. Sourcebook of existing and proposed protected areas in Vietnam. Second edition. Hanoi: BirdLife International in Indochina and the Ministry of Agriculture and Rural Development. 268 p.

Truett G.E. 2006. Preparation of genomic DNA from animal tissues. In: J. Kieleczawa (Ed.): The DNA Book: Protocols and Procedures for the Modern Molecular Biology. Udbury, Massachusetts: Jones \& Bartlett Publisher. P. 33-46.

Vlnová I. 2014. Revision of tapeworms of family Diphyllobothriidae (Eucestoda: Solenophoridae) from the monitor lizards. Mgr. Thesis. České Budějovice, Czech Republic: University of South Bohemia. 61 p.

Waeschenbach A., Brabec J., Scholz T., Littlewood D.T.J., Kuchta R. 2017. The catholic taste of broad tapeworms - multiple routes to human infection. International Journal for Parasitology 47(13): 831-843. DOI: 10.1016/j.ijpara.2017.06.004

Waeschenbach A., Littlewood D.T.J. 2017. A molecular framework for the Cestoda. In: J.N. Caira, K. Jensen (Eds.): Planetary Biodiversity Inventory (2008-2017): Tapeworms from the vertebrate bowels of the Earth. Special Publication No. 25. Lawrence: University of Kansas. P. 431-451.

Zhang G., Chen J., Yang Y., Liu N., Jiang W., Gu S., Wang X., Wang Z. 2014. Utility of DNA barcoding in distinguishing species of the family Taeniidae. Journal of Parasitology 100(4): 542-546. DOI: 10.1645/13-224.1 
МОЛЕКУЛЯРНАЯ И МОРФОЛОГИЧЕСКАЯ ХАРАКТЕРИСТИКА ЛИЧИНОК ПЛОСКИХ ЧЕРВЕЙ, ПАРАЗИТИРУЮЩИХ В РЫБАХ НАЦИОНАЛЬНОГО ПАРКА КАТТЬЕН, ВЬЕТНАМ

\author{
С. Г. Соколов ${ }^{1}$, И. И. Гордеев ${ }^{2,3}$ \\ ${ }^{1}$ Институт проблем экологии и эволючии имени А.Н. Севериова РАН, Россия \\ ${ }^{2}$ Всероссийский научно-исследовательский институт рыбного хозяйства и океанографии, Россия \\ ${ }^{3}$ Московский государственный университет имени М.В. Ломоносова, Россия \\ e-mail: gordeev_ilya@bk.ru \\ Национальный парк Каттьен (Южный Вьетнам) предоставляет уникальную возможность изучения \\ разнообразия паразитов, связанных с животными равнинных тропических лесов и равнинных реч- \\ ных бассейнов Юго-Восточной Азии. В этом исследовании мы приводим морфологическое опи- \\ сание пяти видов метацеркарий Clinostomum sp., Posthodiplostomum sp. 1, Posthodiplostomum sp. \\ 2, Crassiphialinae gen. sp. 1, Crassiphialinae gen. sp. 2, обнаруженных у четырех видов пресновод- \\ ных рыб парка (Rasbora paviana, Trichopodus trichopterus, Anabas testudineus, Channa striata) и их \\ филогенетический анализ, основанный на частичных последовательностях гена 28S pPHК. Тре- \\ матода Clinostomum sp. оказалась филогенетически близкой (возможно, конспецифичной) к мета- \\ церкарии Clinostomum sp., ранее отмеченной в Австралии. Последовательности, идентичные двум \\ Posthodiplostomum sp. и остальным, обнаруженным нами метацеркариям, в базе GenBank отсутству- \\ ют. Филогенетический анализ подтверждает близкородственную связь Crassiphialinae gen. sp. 1 с \\ группой крассифиалиновых трематод Uvulifer spp. + Crassiphiala spp. В то же время, филогенети- \\ ческие связи Crassiphialinae gen. sp. 2 были плохо разрешены. Мы также приводим морфологиче- \\ ское описание плероцеркоида соленофоридной цестоды Scyphocephalus sp. из печени Trichopodus \\ trichopterus и реконструкцию филогении этого паразита, основанную на частичных последователь- \\ ностях генов cox1 и 28S pРНК. Филогенетические анализы объединяют Scyphocephalus sp. в одну \\ группу с Duthiersia expansa, тогда как типовой вид рода Scyphocephalus - S. bisulcatus - выступает в \\ качестве сестринского таксона к виду Duthiersia fimbriata. Таким образом, филогенетические данные \\ ставят под сомнение как монотипию, так и монофилию рода Scyphocephalus. Это вторая зарегистри- \\ рованная находка плероцеркоидов соленофорид и первая в рыбе, как втором промежуточном хозяине \\ цестод этого семейства.
}

Ключевые слова: Clinostomum, Crassiphialinae, Posthodiplostomum, Scyphocephalus, метацеркарии, плероцеркоиды, пресные воды, тропики 